Chirurgia (2020) 115: 476-485

No. 4, July - August

Copyright@ Celsius

http://dx.doi.org/10.21614/chirurgia.115.4.476

\title{
Identifying the Sentinel Lymph Node in Patients with Cutaneous Melanoma - Preliminary Report of a Private Clinic in Bucharest
}

\author{
Florin Bobirca ${ }^{1,2}$, Casandra Coltoiu ${ }^{1}$, Cristina Jauca ${ }^{2}$, Tiberiu Tebeica ${ }^{1}$, Anca Bobirca ${ }^{2}$, Adela Pumnea ${ }^{3}$, \\ Mihaela Leventer ${ }^{*}$
}

'Dr. Leventer Centre, Bucharest, Romania

${ }^{2}$ Carol Davila University of Medicine and Pharmacy, Bucharest, Romania

${ }^{3}$ Gauss Clinics, Bucharest, Romania

*Corresponding author:

Mihaela Leventer, MD

Dr. Leventer Centre, Bucharest, Romania

E-mail: mihaela.leventer@yahoo.com

\section{Rezumat}

Identificarea ganglionului santinela la pacienții cu melanom cutanat - raport preliminar al unei clinici private din București

Introducere:Acuratețea stadializării, alături de reproductibiltatea cartografierii limfatice intraoperatorii şi a biopsiei de ganglion santinelă la pacienții cu melanom s-au bucurat de o validare unanimă în ultimul deceniu. Această tehnică permite depistarea micrometastazelor ganglionare cu ajutorul metodelor imunohistochimice. Studiul de față este menit a prezenta experiența clinicii noastre în ceea ce priveşte protocolul de identificare şi de biopsie a ganglionului santinelă.

Metodă:A fost derulată o analiză retrospectivă în perioada martiedecembrie 2019 ce a cuprins 57 de pacienți cu melanom cutanat la care s-au practicat detectarea şi biopsia excizională a ganglionului santinelă. Intervenția s-a desfăşurat cu ajutorul metodei duble, folosind un colorant vital şi un trasor radioactiv. Au fost extrase informații demografice, precum şi date referitoare la localizarea tumorilor primare, la histologia tumorală şi la nivelul de radioactivitate.

Rezultate: Grosimea Breslow medie a melanoamelor cutanate primare a fost de $2.7 \mathrm{~mm}$. Pentru 56 din cei 57 pacienți incluşi în studiu, s-a identificat cel puțin un ganglion santinelă. Dintre aceştia, $15(26 \%)$ au prezentat minim un ganglion metastatic. Numărul mediu de ganglioni santinelă excizați per pacient a fost de 1.6.

Concluzii: Cartografierea limfatică şi biopsia de ganglion santinelă 
necesită integrarea unei echipe multidisciplinare sofisticate alcătuite din specialişti de medicină nucleară, chirurgie şi de anatomie patologică. În această manieră sunt asigurate atat o stadializare corectă a pacientului cu melanom, cat şi accesul acestuia la terapiile adjuvante inovative, îmbunătățind astfel considerabil prognosticul.

Cuvinte cheie: melanom, nodul limfatic, limfoscintigrafie

\section{Abstract}

Background: The accuracy of the staging, along with the reproductibility of intraoperative lymph car-tography, and lymph node biopsy in patients with malignant melanoma was unanimously validated in the last decade. This technique allows the discovery of lymph node micrometastses with the help of immunohistochemical methods. The goal of the present study is to present the experience of our clinic in identification and biopsy protocol of the lymph node.

Method: A year-long retrospective analysis was running between March 2019 - December 2019 con-cerning 57 patients with cutaneous melanoma on which detection and excisional biopsy of the lymph node was performed. The procedure was performed by the double method using vital dye and a ra-dio-active tracer. Demographic information was filed, as well as data on location of primary tumors, tumor histology, and radioactivity level.

Results: The mean Breslow thickness of primary skin melanomas was $2.7 \mathrm{~mm}$. At least one lymph node was identified in 56 of the 57 patients included in the study. Among those, 15 (26\%) had at least one metastatic node. The mean number of excised lymph nodes per patient was 1.6.

Conclusions: The cartography and biopsy of lymph nodes need the involvement of a complex multidisciplinary team made of nuclear medicine, surgery, and anatomopathology specialists. This way one provides both a correct staging of the patient with melanoma and access to adjuvant innovative therapies, thus considerably improving the prognosis.

Key words: melanoma, lymph node, lymph scintigraphy

\section{Introduction}

The involvement of the lymph node is the most important prognostic factor concerning survival and relapse rate among melanoma patients. Presence of node metastases reduces the survival rate at 5 years by $40-50 \%$. Lymph node invasion is frequently associated with advanced disease stages. In less advanced cases, complete lymphadenectomy is not necessary, as there is no extension of the disease at this level. The histopathological examination is the only one that allows identification of eventual node metastases when the clinical and imagistic examinations are negative $(1,2)$.

Detection of the lymph node remains the only known way until now to avoid an unnecessary regional lymphadenectomy (1).

Herbert L. Snow was the first to propose the removal of regional nodes by elective lymphadenectomy in the year 1892, regardless if a palpable adenopathy was present or not, with the goal of slowing down the progression of the disease (3). The effectiveness of this procedure was long debated. Many prospective randomized studies have proven that elective lymphadenectomy brings no benefit in cases of cutaneous melanoma $(4,5,6)$. Despite those results, an analysis of subgroups in the study by Balch et al. proved there to be an increase of survival among certain categories, namely those aged under 60, with a Breslow index 
between 1 and $2 \mathrm{~mm}$ or with nonulcerated tumors (7).

The main inconvenience of elective lymphadenectomy is that it is expected that only $20 \%$ of patients with cutaneous melanoma of medium thickness develop lymph node metastases, while $80 \%$ of them are exposed to morbidities associated with the procedure, with no concrete therapeutic benefit $(8,9)$.

The concept of sentinel lymph nodes was first introduced by Morton in the early 1990s and is defined as the first regional lymph node where the lymph is drained from the primary tumor. As a result, this works as a "sentinel" for the secondary metastatic node stations, being the first to be affected in case of regional tumoral dissemination (8).

The risk of lymph involvment increases with the thickness of the tumor. However, $90 \%$ of the patients with stage I or II skin melanoma are not showing clinically removable adenopathies, but $16 \%$ of them show microscopic lymph involvment $(10,11)$.

The biopsy of the lymph node plays a prime diagnostic role in melanoma, contributing to the staging of the disease and facilitating selection of patients who may benefit of adjunctive therapy. Moreover, it increases the accuracy of the prognosis - studies demonstrated that patients with a positive lymph node faced a risk of relapse that was 5 times higher at 3 years in comparison with patients with a negative lymph node (12).

Following this technique allows for a more precise tumor staging. Therefore, patients who were otherwise belonging to stage I or II, are now ranked in stage III.

In addition, experimental studies demonstrated that distance metastasis originate more frequently in metastatic adenopathies rather than in primary melanoma. This can be explained by the presence of a cloning selection of metastatic cells which are able to proliferate at node level despite immune defense mechanisms. The capacity to discover secondary node determinations as early as they develop may slow their unavoidable evolution to distance metastases, thus increasing the odds of healing. It is known that lymph node micrometastases become clinically palpable after 18-24 months. This could be a critical period which may make the difference between a healing or a palliative treatment (13).

Moreover, articles published in literature confirm a safe therapeutic profile of the lymph node biopsy in case of pregnant women, both for the mother and the fetus (14).

At the moment, the modality of identification of the sentinel lymph node is the use of a triple technique combining a nuclear relatively simple procedure with another minimally invasive surgical procedure. Before the operation the number and location of the sentinel lymph node and lymph vessels are identified by using dynamic lymphoscintigraphy. Subsequently, the sentinel lymph node and blood vessels are visualized using vital dye, and a radioactive tracer is used in order to reveal the direction of the dissection (15).

Lymph node metastases occur only in $4.5 \%$ of the cases of thin melanoma (thickness less than $1 \mathrm{~mm}$ ), the risk increasing by: thickness of tumor larger than $0.75 \mathrm{~mm}$, level Clark IV or $\mathrm{V}$, or mytotic rate. The sentinel lymph node biopsy is best used in primary tumors with a Breslow index of more than $1 \mathrm{~mm}$ or under 1 $\mathrm{mm}$ if an ulceration is present (16).

Patients with a tumor thicker than $4 \mathrm{~mm}$ show a probability of $40 \%$ of node involvment, as well as an increased risk of distance metastases. However, most of the time adenopathies are not clinically palpable. As a result, lymph node biopsy works as an important prognostic factor, relevant in the prevention of local relapses (17).

Despite those advantages and its widespread use in staging of melanoma and other neoplasies, in our country the technique is still in its first steps. The goal of this analysis was to share pertinent peculiarities of drafting the lymph map and of sentinel lymph node biopsy, the way they are practiced in our clinic. Also, this preliminary report is meant to evaluate the level of invasiveness of this intervention and its contribution to staging patients with melanoma, as well as the importance of its use in a center comprising an experimented multidisciplinary team. 


\section{Materials and Method}

A retrospective analysis of 39 patients subjected to a sentinel lymph node biopsy in our clinic was performed between March 2019 - March 2020. Informed consent of all patients was obtained.

Criteria of inclusion were on a par with present indications of the lymph node biopsy in melanoma (9): a tumoral stage of at least $\mathrm{pT} 1 \mathrm{~b}$, and no more then 8 weeks from the excision of the primary tumor. Criteria of exclusion (9) were clinically detected adenopathies, distance metastases, and excision of the primary lesion with margins larger than 1 $\mathrm{cm}$. This analysis included a pregnant patient whom the procedure was performed on. In addition, the patients eligible for the procedure of sentinel lymph node biopsy were the ones who previously had a local excisional biopsy. This way the regional lymph drainage disturbance was kept to a minimum.

In the case of one patient, the primary tumor was excised in a different department, with wide safety margins and the cutaneous defect was closed with a flap. This botched management made the intervention impossible.

In case of primary tumors located in the head area, we used a mixed surgical team including an oncologic surgeon and oromaxillofacial surgeon.

The first step is performing a pre-op lymphoscintigraphy requires injecting $0.5-1.0 \mathrm{mCi}$ (18.7-37 MBq) radioactive tracer (Nanocol* radioisotopically marked with Technetium$99 \mathrm{~m}), 2-6$ hours before surgery.

In order to assure migration of the radioactive isotope from the injection location to the first lymph node it must be attached to a colloidal substance to transport it. In our clinic we use human colloid albumin with a diameter of 5-80 $\mathrm{nm}$ due to its capacity to be quickly absorbed by the lymphatic system, carried to the first lymph node, and retained long enough to be revealed later. The radiotracer is injected intradermally around the tumor in 2-6 spots. Later on, an external gamma camera (SPECT) records the migration of the isotope in the lymph basin in real time, as a dynamic study and as frozen

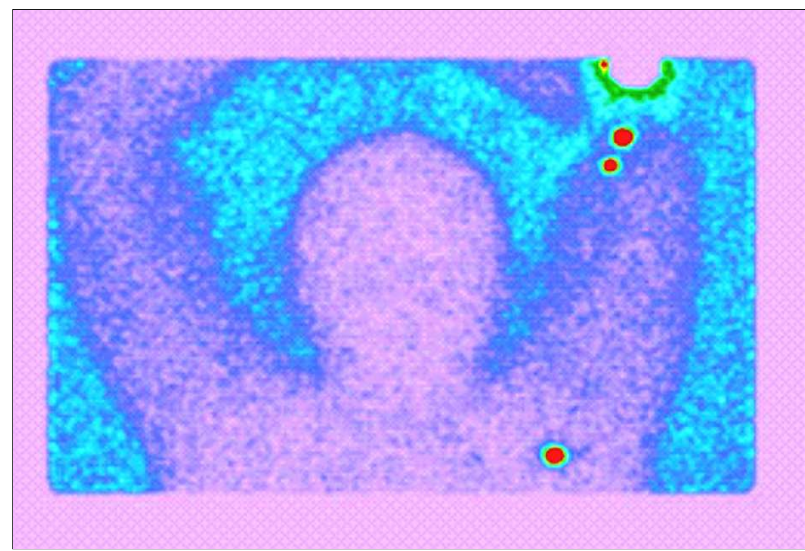

Figure 1. Image of lymph scintigraphy showing the lymph drainage in a patient with primary skin melanoma at the back side of of the left arm

images at various time intervals (Fig. 1).

All procedures are performed in a single day. The sentinel lymph node biopsy is done before the post-biopsy scar excision of the melanoma with safety margins in order to prevent compromising lymph circulation.

In the OR the patients are initially scanned with a gamma probe with the purpose of certifying a proper diffusion of the radioisotope.

As for the actual surgical intervention it is performed depending on circumstances. The intervention can be done under general anesthesia, spinal anesthesia, and in certain cases under spinal anesthesia combined with epidural anesthesia. The anesthesia is followed by an adequate positioning of the patient in order to optimize the discovery of the sentinel lymph node.

At the start of each intervention $1 \mathrm{ml}$ of vital dye consisting of sterile methylene blue is injected intradermally in the proximity of the origin of the primary tumor. The incision is performed 10 minutes later to allow the dye to be taken up by the lymphatic system and be transported towards the proper node basin. The skin incision is based on the evaluation of the topographic projection of radioactivity.

The node basin is approached by an incisional biopsy indicated by the gamma probe. The nodular dissection is oriented both by the visualization of the dyed lymphatic vessels belonging to the node, and by the gamma probe. The visualization of the blue 


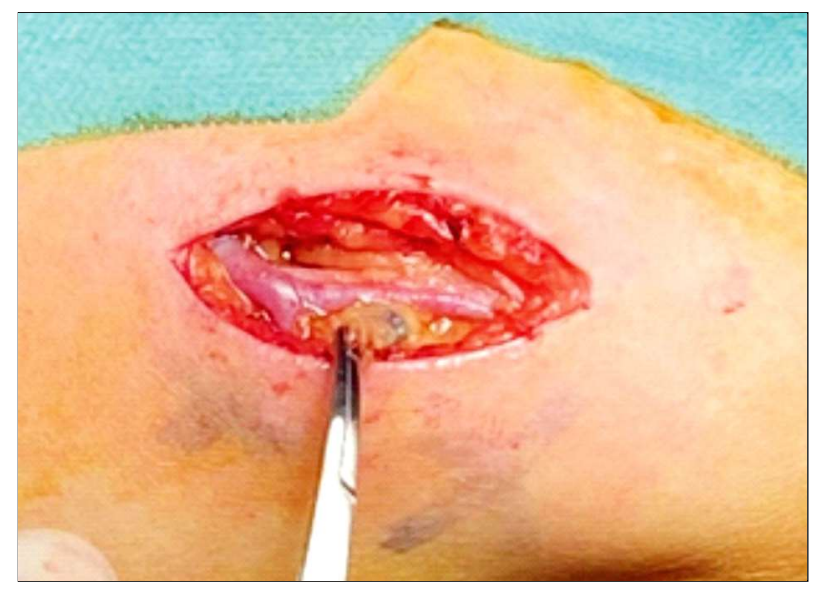

Figure 2. Sentinel lymph node dyed in blue detected in the same patient

color is useful and allows a quick identification of the node which accumulated the most radioactive substance, the socalled "hot spot node" (Fig. 2). The sentinel lymph node is then totally removed along with the afferent and efferent lymphatic vessels of the node, the ones that were identified with vital dye are then ligated with hemostatic clips, because electrocautery of the vessels is not effective. This way one prevents the formation of seromas. The ex-vivo levels of the node radioactivity are recorded with the gamma probe and are noted. With the same probe, we also scanned the node basin left after the removal of the sentinel lymph node in order to eliminate any residual radioactivity. Additional radio-absorbent nodes are also excised. The nodes colored in blue are labeled as sentinel lymph nodes or of those being with significant radioactivity levels. This technique is repeated

Table 1. Demographic information

\begin{tabular}{llr}
\hline $\begin{array}{l}\text { Age } \\
>60 \text { y.0. }\end{array}$ & 20 patients & $35 \%$ of patients \\
$<60$ y.0. & 37 patients & $65 \%$ of patients \\
\hline $\begin{array}{l}\text { Gender } \\
\text { Male }\end{array}$ & 30 patients & $53 \%$ of patients \\
Female & 27 patients & $47 \%$ of patients \\
\hline Location of primary tumor & & \\
Trunk & 33 patients & $58 \%$ of patients \\
Limbs & 14 patients & $24.5 \%$ of patients \\
Head extremity & 10 patients & $17.5 \%$ of patients \\
\hline
\end{tabular}

until no level of radioactivity surpasses $10 \%$ of the most radioabsorbent node.

Most of the sentinel lymph nodes are easily identified with the probe because their radioactivity levels are higher than the surrounding subcutaneous tissue with more than 600 .

The post-biopsy scar of the melanoma is later excised with safety margins ranging from 1 to $2 \mathrm{~cm}$ depending on thickness and location of the primary lesion.

The last stage is a careful histopathologic evaluation in order to provide the accuracy of the staging. One performs sectioning of the lymph nodes, using hematoxylin eosin stain (H\&E), as well as immunohistochemistry with HMB-45 and S-100 antibodies. Serial sections improve the chances to detect micrometastases.

\section{Results}

The analysis included 57 patients (30 males and 27 females) diagnosed with melanoma, who were subjected to sentinel node biopsy. The average age was 53 y.o. The study included a pregnant patient. The primary melanoma was located on the trunk in 33 patients, on limbs in 14 patients and on the head extremity in 10 patients (Table I). As for histopathologic peculiarities, the average Breslow thickness was $2.7 \mathrm{~mm}$ (Table 2). The tumor stages were: 14 patients in stage pT 1,16 patients in stage pT2, 18 patients in stage pT3 and 9 patients in stage pT4 (Table 3). In 22 patients, ulceration was present.

Table 2. Histopathologic information

\begin{tabular}{lcc}
\hline $\begin{array}{l}\text { Breslow index } \\
<1 \mathrm{~mm}\end{array}$ & 12 patients & $21.1 \%$ of patients \\
$1-2 \mathrm{~mm}$ & 23 patients & $40.3 \%$ of patients \\
$2-4 \mathrm{~mm}$ & 15 patients & $26.3 \%$ of patients \\
$>4 \mathrm{~mm}$ & 7 patients & $12.3 \%$ of patients \\
\hline Presence of ulceration & & \\
YES & 22 patients & $39 \%$ of patients \\
NO & 42 patients & $74 \%$ of patients \\
\hline Status of sentinel node & & \\
Positive & 15 patients & $26 \%$ of patients \\
Negative & 42 patients & $74 \%$ of patients \\
\hline
\end{tabular}


Table 3. Classification of patients by tumor stage and number of positive sentinel nodes

\begin{tabular}{ccc}
\hline Tumor stage & $\begin{array}{c}\text { Number } \\
\text { of patients }\end{array}$ & $\begin{array}{c}\text { Number of positive } \\
\text { nodes }\end{array}$ \\
\hline pT1 & 14 & $24.5 \%$ \\
\hline pT2 & 16 & $28 \%$ \\
\hline pT3 & 18 & $31.5 \%$ \\
\hline pT4 & 9 & $16 \%$ \\
\hline
\end{tabular}

In 56 of the 57 patients at least one sentinel lymph node was identified. Out of the 88 sentinel lymph nodes which were exposed, the pre-op lymph scintigraphy showed drainage in 63 lymph basins. Drainage into only one lymph basin was revealed in 50 patients, and drainage in two lymph basins was seen in 5 patients and in three lymph basins in 1 patient. The latter had the primary tumor on the scalp. The average number of excised sentinel nodes per patient was 1.6.

Of the 57 patients included in the study, $15(26 \%)$ were found with at least one metastatic sentinel node. Among the 15 subjects, 10 were initially diagnosed with ulcerated melanoma.

In cases with positive sentinel node, the BRAF mutation occured from its level.

The most patients with a positive sentinel node were the ones in stage tumor pT4 (7 patients), followed by stage pT3 (5 patients) and stages pT2 (2 patients), respectively p $\mathrm{T} 1$ (1 patient). This fact confirms the results from literature that a thicker primary tumor is associated with an increased risk of node secondary determination.

The surgery was not followed by post-op complications in neither of the patients.

\section{Discussion}

The management of nodular micrometastases evolved significantly due to improved staging techniques and technology associated with detection of sentinel nodes. From a biological point of view, this technology provided a new perspective on skin lymph draining and made evident a larger incidence of nodular metastases which are not clinically operable.

\section{Pre-op Lymph Scintigraphy}

Lymph scintigraphy is an important first step forward and serves four goals: it indicates the draining area of the lymph node; it shows the number of sentinel nodes and makes their differentiation from secondary nodes easier; it allows the nuclear medicine doctor to mark the location of the sentinel node at the cutaneous level; it reveals an eventual wrong lymph drain, in the absence of the target lymph basin (9). The type of the lymph draining is often unpredictable, and the primary tumor may drain exclusively from a sentinel node located outside of the standard node groups. For instance, the sentinel node may be located in the scapular or epitrochlear regions, popliteal space, or ribs in the case of melanomas on trunk or limbs (18).

In the studies of the Sydney Melanoma Unit (19), as well as in Roozendaal case log (20) and Sumner (21), it reported a frequency of $5 \%$ of those locations. An eventual failure in detection and histologic analysis of the ectopic sentinel nodes could result in an incorrect staging of the tumor and also could mean the source of later regional or distant metastases for the patient.

Images provided by pre-op lymph scintigraphy changes the classical paradigm "open and observe" into an approach "observe and open" because it allows visualization of the pattern of lymph draining of melanoma, thus increasing the accuracy of surgical intervantion (17).

The technique of cutaneous lymph scintigraphy includes an intradermic injection in $2^{-}$ 6 points of a quantity of colloidal technetium $0.5-1.0 \mathrm{mCi}(18.7-37 \mathrm{MBq})$ or $99 \mathrm{~m} \mathrm{Tc}-$ Nanocol in the proximity of the tumor. This radioactive agent has the advantage of speedy movement to the regional nodes and stays at this level for a few hours. The intradermic injection, unlike the subcutaneous injection, is important because the interstitial pressure seems to facilitate the access of the isotope into the regional lymph system. As a rule, the radioisotope is transported in a couple of minutes into the regional lymph nodes (22). 
In our clinic the lymph scintigraphy is performed most often in the morning, 2-6 hours prior to the surgical intervention, in order to avoid extra travel of the patient the next day. Occasionally, the long time between the injection of the radioactive agent and the surgery results in the migration into the next node relay, thus causing an unnecessary removal of several lymph nodes.

We use technetium thanks to its properties: the short half life of 6 hours and its energy of $140 \mathrm{kEV}$. The administered dose is minimal and no special precautionary measures are necessary to keep down radiation levels for the patient or the surgical team (23).

There are many factors which may cause an erroneous identification of the sentinel node. For example, the cases where excisions with margins larger than $1.5 \mathrm{~cm}$ were performed, or where the cutaneous defect was closed with rotation flaps are not recommended for sentinel node biopsy. Another example is where a history of surgery has modified the lymph drainage in the regional nodes. These situations compromise the accuracy of the lymph "mapping" and the sentinel node biopsy which may lead to a contraindication of the intervention $(22,23)$.

\section{The Technique of Injection of Vital Dye}

Morton and collaborators investigated a number of vital dyes, like isosulfane blue, Patent Blue- $\mathrm{V}$, fluorescein or methyl blue. Of these, the Patent Blue-V and isosulfane blue were noted with best results in the accuracy of identification of the regional lymph drainage (14). Both substances penetrated the lymphatic circulation quickly, with a minimal peritissular diffusion. Moreover, the strong blue color was easily visualized and allowed easy identification of the exposed lymph nodes. The use of vital dyes was not followed by significant side effects, except for minor allergic reactions. However, a few cases of severe anaphylactic reactions were reported (24).

In our clinic we use sterile methyl blue $0.5 \%$ in a quantity of $1 \mathrm{ml}$ (cc). More recent studies have confirmed that following its use, similar results with other dyes were obtained. The advantage to this dye was its lower price and reduced risk of allergic reactions (24). The methyl blue is injected intradermally around the primary tumor. The vital dye must not be injected directly at the level of origin of the biopsy. Applying a slight pressure at injection location increases the intralymphtic pressure and reduces the transit time towards the lymph basin.

The amount of injected substance depends on the location and the distance between the seat of the primary melanoma and the regional lymph basin. Thus, in case of tumors on the distal extremities one must inject a larger volume (about $1 \mathrm{ml}$ ) than the ones on proximal extremities $(\max .0 .5 \mathrm{ml})$. The vital dye must be injected in four quadrants around the postbiopsy scar. Smaller lesions of post excisional biopsy need a more reduced quantity of dye.

The primary tumors on the face, extremities, or trunk located at no more than 5-6 cm distance from the regional lymph basin should receive a lower volume of lymphophilic product (max. $0.25 \mathrm{ml}$ ). It may diffuse in the soft tissues and obscure the lymph canals $(25,26)$.

\section{The Use of a Gamma Probe in an Intraoperative Procedure}

The gamma probe allows a minimal dissection in the direction of the sentinel node during surgery. It is used immediately after the incision of the superficial fascia - in case the blue dye is not visible - with the purpose of minimizing the amount of dissection necessary to identify the sentinel node. Once removed, the node is tested for recording the radioactive load. The registered value must be at least 3 times larger than the residual value measured at the node basin level after the excision of the sentinel node. As a result, a node dyed in blue and "hot" after using the gamma probe, is without a doubt a sentinel node. However, if the surgery was performed sooner than 2 hours after the intradermic injection of the isotope, it may happen that the node is colored in blue, but may not be "hot" (26). 
Sometimes the gamma probe cannot selectively detect the activity in a sentinel node due to its proximity to the primary tumor. In this case it is better to perform a wide excision of the primary skin melanoma, thus removing radioactivity in the zone and facilitating the discrimination of the node in the explored basin (27).

The use of the gamma probe associated with the lymph "mapping" and has greatly improved the accuracy of sentinel node identification compared with the isolated use of the blue dye (99\% vs $95 \%)(28,29)$. It was noticed that the rate of false negative results is $5 \%$, and minor complications occur in $10 \%$ of the cases (30).

\section{The Histopathological Analysis of the Sentinel Node}

The decision of the tumor status is based on analysis of the H\&E (Fig. 3) dyed sections associated with immunohistochemistry tests for melano-cytic antigens. Traditionally, Melan A, S100, and HMB45 are used, but a new generation of markers like Tyrosinase or SOX10, may increase the sensitivity and specificity of the immunohistochemical reaction. Immuno-histochemy thus increases the probability of detecting positive sentinel nodes.

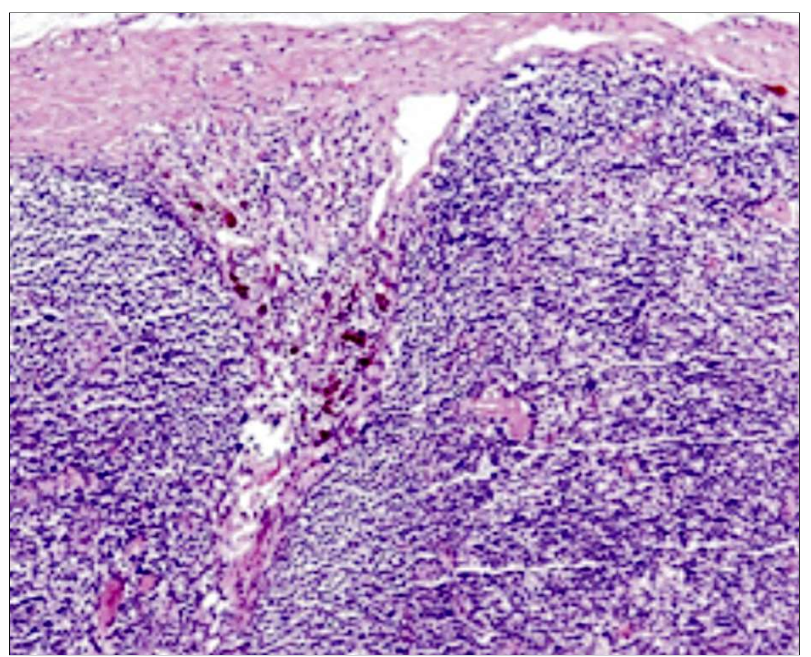

Figure 3. Subcapsular micrometastasis in HE coloration magnification $200 x$
The protein $\mathrm{S} 100$ is a sensitive marker present in all cutaneous melanomas. The pathologist must identify the epithelioid cells, oval or fusiform (as a rule in subcapsular sinus) which reveal epitopes of protein S100 both in cytoplasm and in nucleus. However, there are also other lymph node cells revealing protein S100. They are mostly dendritic cells, besides collections of capsulated or trabecular nevocytes and Schwann cells.

Although HMB-45 is a more specific marker than tumor cells, in $20 \%$ of cases the melanoma doesn't reveal this epitope. Unless protein $\mathrm{S} 100$, the HMB-45 is revealed at cytoplasm level. The dendritic cells or capsulated nevocytes do not reveal the HMB-45 (27). The antibody Melan A is a marker both sensitive and specific for the identification of micrometastases in the sentinel node (Fig. $\phi$ ). It detects most mela-nomas, but certain tumoral subpopulations such as melanomas with fusiform cells may not be revealed by Melan A. Those can be identified if the testing is performed complementary with more specific melanocytic antibodies (Tyrosinase, SOX10, etc.) (31).

One can conclude with certainty that the biopsy technique of the sentinel node brings a significant contribution in the staging of the patients with melanoma and their access to adjuvant therapies. This provides extra information about the lymph dissemination by

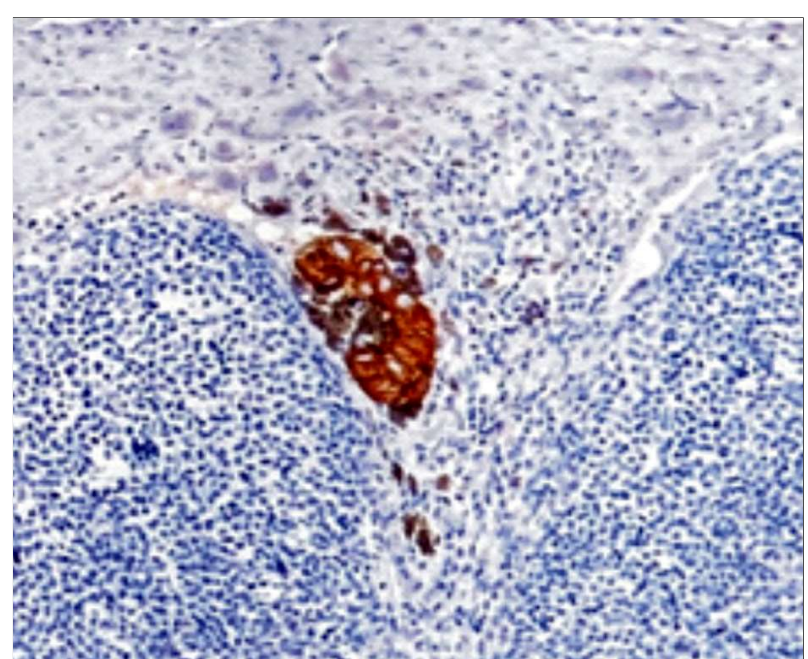

Figure 4. Revealing positivity of the tumor cells for Melan-A 
analizing multiple sections of the sentinel none, as well as by special techniques of immune histochemy, avoiding the side effects of lymph adenectomy. Moreover, the staging allowed by this technique dictates the subsequent protocol of melanoma patient monitoring.

The analysis performed in our clinic showed the applicability of the technique of sentinel node biopsy in pregnant women, as well as reduced invasiveness of the procedure. Also, this report revealed the presence of metastatic nodes in $26 \%$ of the examined parients, most of them (47\%) belonging to stage $\mathrm{pT} 4 \mathrm{~b}$. This fact underscores the relation between the Breslow score and the risk of secondary node determination. In the same time one can observe that the success of the intervention depends on a close cooperation between the nuclear physician, the surgeon and the anatomopathologist. Moreover, the location of the sentinel node at the head requires an oromaxilofacial surgeon. Each member of the team plays a critical role in a high rate of success in identifying the localization of the node micrometastases.

\section{Acknowledgements}

This study was conducted based on data obtained with the consent of the patients. The statistical data used in the study are taken from the internal database of the clinic.

\section{Conflict of Interest}

Patients who participated in the study signed the consent form, giving their agreement free of any coercion or pressure.

\section{References}

1. Greenlee RT, Murray T, Bolden S, Wingo PA. Cancer statistics, 2000. C.A. Cancer J. Clin. 2000;50:7-33.

2. Hiram S, Cody III. Sentinel Lymph Node Biopsy. November 8, 2001; p. 71-73.

3. Snow HL. Melanotic cancerous disease. Lancet. 1892;2:872.

4. Cascinelli N, Morabito A, Santinami M, MacKie RM, Belli F. Immediate or delayed dissection of regional nodes in patients with melanoma of the trunk: a randomised trial. WHO Melanoma Programme. Lancet. 1998;351(9105):793-6.
5. Veronesi U, Adamus J, Bandiera DC, Brennhovd O, Caceres E, Cascinelli $\mathrm{N}$, et al Delayed regional lymph node dissection in stage I melanoma of the skin of the lower extremities. Cancer. 1982; 49(11):2420-30.

6. Sim FH, Taylor WF, Pritchard DJ, Soule EH. Lymphadenectomy in the management of stage I malignant melanoma: a prospective randomized study. Mayo Clin. Proc. 1986;61(9):697-705.

7. Balch CM, Soong SJ, Bartolucci AA, Urist MM, Karakousis CP, Smith TJ, et al. Efficacy of an elective re-gional lymph node dissection of 1 to $4 \mathrm{~mm}$ thick melanomas for patients 60 years of age and younger. Ann Surg. 1996;224(3):255-63.

8. Morton DL, Wen DR, Wong JH, Economou JS, Cagle LA, Storm FK, et al. Technical details of intraoper-ative lymphatic mapping for early stage melanoma. Arch Surg. 1992;127(4):392-9.

9. Gonzalez A. Sentinel Lymph Node Biopsy: Past and Present Implications for the Management of Cutaneous Melanoma With Nodal Metastasis. Am. J. Clin. Dermatol. 2018;19(Suppl 1):24-30.

10. Wright FC, Souter LH, Kellett S, Easson A, Murray C, Toye J,et al. Primary excision margins, sentinel lymph node bi-opsy, and completion lymph node dissection in cutaneous melanoma: a clinical practice guideline. Curr Oncol. 2019;26(4):e541-e550.

11. Morton DL, Thompson JF, Cochran AJ, Mozzillo N, Nieweg OE, Roses DF, et al. Final trial report of sentinel-node biopsy versus nodal observation in melanoma. N Engl J Med. 2014;370(7): 599-609.

12. Statius Muller MG, Van Leeuwen PA, De Lange-De Klerk ES, Van Diest PJ, Pijpers R, Ferwerda CC, et al. The Sentinel Lymph Node Status Is an Important Factor for Predicting Clinical Out-come in Patients With Stage I or II Cutaneous Melanoma. Cancer. 2001; 91(12):2401-8.

13. Balch CM, Soong S, Ross MI, Urist MM, Karakousis CP, Temple WJ, et al. Long-term results of a multi-institutional randomized trial comparing prog-nostic factors and surgical results for intermediate thickness melanomas (1.00-4.00 mm). Ann Surg Oncol. 2000;7(2): 87-97.

14. Robert H, Andtbacka I, Matthew R, Donaldson T, Bowles L, Bowen GM, et al. Sentinel Lymph Node Biopsy for Melanoma in Pregnant Women. Ann Surg Oncol. 2013;20(2):689-96. Epub 2012 Oct 6.

15. Tardelli S, Mazzarri S, Rubello D, Gennaro M, Fantechi L, Duce V, et al. Sentinel lymph node biopsy in cutaneous melanoma: standard and new technical procedures and clinical advances. A systematic review of the literature. Clinical Nuclear Medicine. 2016;41(12):e498-e507.

16. Cordeiro E, Gervais MK, Shah PS, Look Hong NJ, Wright FC. Sentinel lymph node biopsy in thin cutaneous melanoma: a systematic review and meta-analysis. Ann Surg Oncol. 2016;23: 4178-4188.

17. Perissinotti, A., Rietbergen D., Vidal-Sicart, S., Riera, A.A., Valdés Olmos, R.A., - Melanoma and nuclear medi-cine: new insights and advances. Melanoma Manag. 2018, Jun; 5(1): MMT06.

18. Kapteijn BA, Nieweg OE, Valdés Olmos RA, Liem IH, Panday RK, Hoefnagel CA, et al. Reproductibility of lymphoscintigraphy for lymphatic mapping in patients with cutaneous melanoma. J Nucl Med. 1996;37(6):972-5.

19. Uren RF, Howman-Giles R, Thomson JF, Quinn MJ, O'Brien C, Shaw HM, et al. Lymphatic drainage to triangular intermuscular spacelymph nodes in melanoma on the back. J Nucl Med. 1996; 37(6):964-6.

20. Roozendaal GK, de Vries JD, Van Poll D, Jansen L, Schraffordt Koops $H$, Nieweg OE, et al. Sentinel nodes outside basins in patients with melanoma. Br J Surg. 2001;88(2):305-8.

21. Sumner WE, Ross MI, Mansfield PF, Lee JE, Prieto VG, Schacherer, $\mathrm{CW}$, et al. Implications of lymphatic drainage to unusual sentinel lymph node sites in patients with primary cutaneous melano-ma. 
Cancer. 2002;95(2):354-360.

22. Miner TJ, Shriver CD, Flicek PR, Miner FC, Jaques DP, ManiscalcoTheberge ME, et al. Guidelines for the safe use of radioactive materials during localization and resection of the sentinel lymph node. Ann Surg Oncol. 1999;6(1):75-82.

23. Moncayo VM, Aarsvold JN, Alazraki NP. Lymphoscintigraphy and sentinel nodes. J Nucl Med. 2015;56(6):901-7.

24. Wong $\mathrm{JH}$, Cagle LA, Morton D. Lymphatic drainage of skin to a sentinel lymph node in a feline model. Ann Surg. 1991; 214(5):637-41.

25. Reintgen DS, Cruse CW, Wells K, Berman C, Fenske N, Glass F, et al. The orderly progression of melanoma nodal metastases. Ann Surg. 1994;220(6):759-67.

26. Park JS, Chang IT, Park SJ, Kim BG, Choi YS, Cha SJ, et al. Comparison of ex vivo and in vivo injection of blue dye in sentinel lymph node mapping for colorectal cancer. World J. Surg. 2009;
33(3):539-46.

27. Pijpers R, Borgstein PJ, Meijer SJ, O S Hoekstra, van Hattum LH, Teule GJ. Sentinel node biopsy in melanoma patients: dynamic lymphoscintigraphy followed by intraoperative gamma probe and vital dye guidance. World J Surg. 1997;21(8):788-92; discussion 793.

28. Kapteijin BA, Nieweg OE, Liem I, Mooi WJ, Balm AJ, Muller SH, et al. Localizing the sentinel node in cutaneous melanoma: gamma probe detection versus blue dye. Ann Surg Oncol. 1997;4(2):156-60.

29. Krag DN, Meijer SJ, Weaver DZI, Loggie BW, Harlow SP, Tanabe KK, et al. Minimal acces surgery for staging of malignant melanoma. Arch Surg. 1995;130(6):654-8; discussion 659-60.

30. Chen SL, Iddings DO DM, Scheri RP, Bilchik AJ. Lymphatic mapping and sentinel node analysis: current concepts and applications. C.A. Cancer J Clin. 2006;56(5):292-309; quiz 316-7.

31. Cochran AJ. The pathologist's role in sentinel lymph node evaluation. Semin Nucl Med. 2000;30(1):11-7. 